\title{
Patent Activity of Start-Ups and the Structuring of Venture Lending Contracts*
}

\author{
Mischa Hesse, Eva Lutz \\ Heinrich Heine University Düsseldorf, Germany
}

\begin{abstract}
This paper empirically examines the effect of patents on capital costs in venture lending contracts. Based on a proprietary dataset entailing 119 venture lending contracts issued by a European venture lending fund between 2002 and 2009 in Europe, the United States, and Israel, we conduct the first quantitative empirical analysis on venture lending as an innovative form of financing for entrepreneurial firms. Our results show that the presence of at least one granted or pending patent negatively influences direct (credit spread) and indirect (warrant coverage) costs of venture lending contracts. Thus, the presence of patents conveys information and is a signal of quality to the payoff distribution of the venture loans. Furthermore, we show that the company development stage negatively influences the relation between patents and capital costs, i.e., in later stages, patents seem to represent a less relevant quality signal than in earlier stages.
\end{abstract}

Keywords: venture lending, venture debt, patent signaling, intellectual property, collateralization

\section{Introduction}

Venture lenders provide individually structured debt financing for young and innovative companies as interim financing to grow the company's operations and to reach either another venture capital financing round under improved terms or an outright exit (Ibrahim, 2010). The unique business model of venture lenders seems to contradict entrepreneurial finance theory. High levels of uncertainty reflected in the liability of smallness and newness (Brüderl, Preisendörfer, \& Ziegler, 1992) lead to the expectation that debt-based financing forms are seldom suitable for innovative start-ups due to the underlying business and financial risks (Block, De Vries, Schumann, \& Sandner, 2014; Colombo \& Grilli, 2007; Westhead \& Storey, 1997). Our aim is to understand how venture lenders are able to overcome these obstacles and to structure their financing instruments according to the inherent risks. Previous theoretical and interview-based studies have indicated that the intellectual property in young and innovative companies is a crucial factor in the venture lending decision (Fischer \& De Rassenfosse, 2012; Ibrahim, 2010). We extend this literature by empirically examining whether the presence of patents offers a quality signal to venture lenders and leads to an adaptation of the capital costs embedded in venture lending contracts.

\footnotetext{
${ }^{*}$ Acknowledgements: The authors gratefully acknowledge the Coller Institute of Venture (CIV) at Tel Aviv University for partial funding of this research project.

Mischa Hesse, research assistant and doctoral candidate, Riesner Endowed Professorship in Entrepreneurship/Entrepreneurial Finance, Heinrich Heine University Düsseldorf. Email: Mischa.Hesse@uni-duesseldorf.de.

Eva Lutz, professor, Riesner Endowed Professorship in Entrepreneurship/Entrepreneurial Finance, Heinrich Heine University Düsseldorf.
} 
Through patents, the start-up is protected against the use of its innovative technology, method, or procedure by other firms leading to an advantage over current or potential future competitors. In addition, patents convey firm characteristics such as technological and specific knowledge, as well as innovativeness and creativity, to third parties, which reduces their information asymmetries (e.g., Hsu \& Ziedonis, 2013; Long, 2002). For equity investors, the current literature shows that intellectual property in the form of patents can serve as a signal for the quality of young and innovative companies. Entrepreneurial firms with patent activity are more likely to close venture capital financing rounds (Audretsch, Bönte, \& Mahagaonkar, 2012; Cao \& Hsu, 2011; Engel \& Keilbach, 2007; Haeussler, Harhoff, \& Mueller, 2014), and filing patents leads to higher valuations by venture capitalists (Bloom \& Van Reenen, 2002; Hsu \& Ziedonis, 2013; Lerner, 1994). However, due to fundamental differences in the business model of venture capitalists and venture lenders, these results cannot readily be applied to venture lending.

Venture capitalists are focused on identifying start-ups that offer high future returns through a successful exit (e.g., Cumming, 2005; 2007; Sahlman, 1990). In contrast, venture lenders rely on steady income streams through the receipt of interest payments and principal repayment (Ibrahim, 2010). When selecting start-ups, venture lenders, therefore, have to focus on limiting the downside risk with the upside only modestly important. While patents were shown to be a signal for the upside potential, it is questionable whether patents also convey information on the downside risk. At least in the short term, the costs associated with patents put pressure on the start-up's liquidity, and positive cash flows from patents might fall outside the venture lender's time horizon. In addition, in venture lending, the entrepreneur and involved venture capitalist(s) are joint equity holders stacked against the venture lender as the debt provider. The venture lender holds a derivative security against the value of the asset and is likely to see their claims at least partly as an option on the claim of the venture capitalist. Quality signals for the start-up might hence be less important for the venture lenders as they are relying on piggybacking off the venture capitalists. In our view, therefore, it is relevant to further describe the role of patents for the lending decision and to identify the consequences of patent activity on the particular terms of a venture loan.

With our access to internal data reports of a venture lending fund with high granularity at the deal level, we are able to investigate actual lending deal structures, which open new insights into the underlying decision processes of the lender and the consequences for the borrower. We systematically analyze whether and how the presence of granted and pending patents impacts the lending deal structures. In other words, do granted or pending patents impact: (1) the credit spread; and/or (2) the warrant coverage of a venture loan? Furthermore, we examine how company development stage influences the relation between capital costs and the presence of granted or pending patents.

Our analysis uses a proprietary dataset including 119 venture loans that were issued between 2002 and 2009 in Europe, the United States, and Israel by a European venture lending fund. To our knowledge, this is the only comprehensive dataset that exists for venture lending and provides the first opportunity to gather empirical evidence on this innovative form of start-up financing. The results show that the presence of patents has a significant and economically relevant impact on capital costs - including both direct and indirect costs - in venture lending contracts. Furthermore, we show that the relation between the presence of patents and direct capital costs is particularly strong in ventures at an early development stage. 
The study extends the current literature in three different fields of academic research regarding the financing of entrepreneurial firms. First, we extend the literature on venture lending by contributing the first empirical analysis of factors that influence capital costs in venture lending contracts. Second, we contribute to the patent signaling theory by revealing that patents provide a signal of quality not only to equity investors but also to the payoff distribution parameters that are applicable principally to debt providers such as venture lenders. Thus, patents are able to convey information that is also relevant to the downside risk to venture lenders. Furthermore, we show that patents are particularly relevant when companies are in their earlier development stages. Third, we extend the literature on entrepreneurial finance that suggests that young and highly innovative entrepreneurial firms often have limited access to debt financing due to the unavailability of tangible securities and high information asymmetries and, thus, are mostly equity financed (Cosh, Cumming, \& Hughes, 2009; Denis, 2004; Hellmann \& Puri, 2002; Kaplan \& Strömberg, 2004). Our data suggest that venture lending, under certain conditions, can be an appropriate financing instrument for young and innovative ventures.

We proceed as follows: The next section introduces the venture lending business model, presents the theoretical background on the determinants of capital costs, and develops hypotheses on the relation between patents and capital costs. Section 3 presents the empirical strategy, as well as descriptive statistics and the dependent and independent variables, used in our regression models. In Section 4, we present the empirical results. Section 5 details the robustness check of the results. Finally, we conclude in Section 6.

\section{Theoretical Background and Hypotheses Development}

\section{Patents and Capital Costs in Entrepreneurial Finance}

Venture loans are individually structured debt-financing instruments for young innovative firms that provide interim financing for operational growth and to extend the cash runway between venture capital funding rounds (Ibrahim, 2010; Rhodes-Kropf \& Leamon, 2010). However, debt financing is strongly dependent on tangible assets or positive cash flows as securities, which the companies have to provide in order to get debt capital (Berger \& Udell, 1990; Cumming \& Fleming, 2013). Young and highly innovative firms often do not have tangible assets or positive cash flows to provide as security (Achleitner, Braun, \& Kohn, 2011; Berger \& Udell, 1998; Cosh et al., 2009). However, venture loans enable those companies to obtain debt capital from lenders by relying on alternative forms of securitization. The lack of track records and the unavailability of tangible securities require these alternative instruments or assets such as intellectual property or a strong investor-backing to secure the repayment of the loan. Another characterizing instrument in venture lending deals is the warrant coverage, which presents an option for the venture lender on the borrower's equity stake and is an additional income source for the lender compared to traditional bank loans (Roberts, Sahlman, \& Kind, 2008).

Although venture lending appeared in the 1980s in the United States and today has an established market position in countries including the United States, Israel, and the United Kingdom (Roberts et al., 2008), it has received little attention in academic research. Previous research on venture lending has focused on general explanations and analyses regarding the lending decision and underlying assumptions. Based on hand-collected interview data, Ibrahim (2010) described the structure and contract design of venture loans in general. He pointed out that venture capital backing may substitute for positive cash flows and tangible assets and that patents support the collateral position of the lender. De Bettignies and Brander (2007) dealt with the choice of entrepreneurial firms between bank finance and venture capital. They theoretically examined the consequences 
of this choice on the entrepreneurial firm regarding control rights, ownership rights, managerial contributions, and the cost of capital. Their study emphasizes that entrepreneurs have the choice between debt and equity and that the entrepreneurs consider aspects like dilution and control rights to balance out which terms of different financing instruments are favorable for them.

Fischer and De Rassenfosse (2012) conducted a choice experiment with 55 senior venture lenders on determinants that influence the lending decision of venture debt firms. Their key result was that venture capital backing can substitute for the start-up's cash flow, but this effect is only observable for early-stage start-ups. Additionally, they stated that the presence of patents facilitates the lending decision by serving as collateral for the venture lender. Offering intellectual property in the form of patents as collateral is likely to increase the likelihood of repayment of venture loans. Additionally, a higher activity in the secondary market for patents stimulates the collateral-based debt financing, which emphasizes that patents can serve as collateral and could hence be an important factor in the decision-making process for debt providers for innovative companies (Hochberg, Serrano, \& Ziedonis, 2014).

Due to the lack of deal-level data, the current literature on venture lending is either interview-based and theoretical or based on choice-experiments. Quantitative empirical studies regarding the determinants of venture lending contracts are still missing in this strand of research. In our study, we build on the existing literature and focus on the relevance of patents on venture lending contracts and how the presence of patents affects the costs of venture loans. While the existing theoretical studies show that patents are likely to be relevant in the lending decisions of venture loans, we are able to quantify this effect due to a proprietary dataset. In particular, we analyze how patents impact the cost structure of venture loans.

The most discussed and well-known aspect regarding patents is that patenting protects intellectual property against the use of a specific technology, method, procedure, or new substance by competitors (e.g., Haeussler et al., 2014; Hsu \& Ziedonis, 2013; Long, 2002; Mann, 2005; Teece, 1986). Thus, the value of patents stems from the exclusive right to use these technologies and to hinder competitors from market entry and imitation.

In the software industry, more patents are granted, the higher market entry barriers are. This emphasizes that patents help to protect start-ups against competitors and to save market niches, entirely new markets, or submarkets (Cockburn \& MacGarvie, 2011). Thus, companies who own strong patents in their field have an advantage over their current and potential future competitors.

In addition, patents can have more functions than just being valuable regarding product markets and exclusivity rights as they are able to convey certain information to third parties. Holding patents conveys positive related information because patents imply firm characteristics, such as technological and specific knowledge, newness, and creativity. In pre-revenue start-ups, patents are one of the few vehicles by which value can be transformed from intangible to tangible property. Due to the conveyance of information to third parties, information asymmetries can be reduced and consequently patents can have a positive influence on the firm's performance (Long, 2002). Moreover, the creation and invention of new technologies, procedures, or treatments need financial as well as human resources. Costs are particularly high in cases where companies want to ensure patent protection for their invention in a number of countries (Sandner \& Block, 2011). Furthermore, patents have to be filed at a patent office where they will be reviewed and, in the best case, finally granted. Thus, due to the patenting process and the patent reports of the patent offices, patents are observable and verifiable by outsiders. 
Regarding equity providers, an empirical study by Conti, Thursby, and Rothaermel (2013) on 226 high-tech start-ups has shown that patents signal quality to venture capitalists and business angels. Moreover, the study revealed that patents are more highly valued by venture capitalists than capital by private informal sources such as family or friends. Additionally, the authors found that patents have a higher impact on the financing of business angels than on money from family and friends. Overall, the authors concluded that patents provide a signal of quality to early-stage equity providers.

Based on 370 venture-backed semiconductor start-ups, Hsu and Ziedonis (2013) showed that patent activity has a positive effect on obtaining venture capital from a highly reputable venture capitalist, on capital costs within several venture capital financing rounds, and on share prices for start-ups that are going public. Their results indicate that successful patenting is more influential for entrepreneurial firms that lack potential quality signals and are in earlier stages of financing. This result is in line with prior studies that reveal that entrepreneurial firms that are filing patents are more likely to receive venture capital (Audretsch et al., 2012; Cao \& Hsu, 2011; Engel \& Keilbach, 2007; Haeussler et al., 2014). Consequently, patenting leads to higher valuations of the start-ups when they are assessed by venture capitalists (Bloom \& Van Reenen, 2002; Hsu \& Ziedonis, 2013; Lerner, 1994). For venture capitalists, patents are considered as an essential factor in their investment decision because they can be sold in the case of a write-off of the portfolio company (Hall \& Harhoff, 2012; Kamiyama, Sheehan, \& Martinez, 2006).

Haeussler et al. (2014) went one step further and showed that not only patent applications and granted patents signal quality to outside equity investors but that the filing of patents and the underlying patenting process is also positively related to venture capital funding. Hence, the patenting process itself uncovers relevant information to third parties. Information is revealed due to search reports, citations, and commercial information about the patents during the filing process. Patenting processes affect the likelihood of venture capital funding and provide more information to investors, thereby supporting them in updating evaluations regarding the quality of the entrepreneurial firms.

Regarding venture lending, there are experimental indications that patents serve as collateral to debt providers and, in particular, to venture lenders (Fischer \& De Rassenfosse, 2012). In this study, we build on these results and delve deeper into the role of patents in structuring venture lending contracts. So far, there has been no empirical study regarding this topic, and the signaling effect of patents on venture capitalists is not readily transferrable to venture lending. Equity investors focus on the upside return potential (Cumming, 2005; 2007; Sahlman, 1990) whereas venture lenders focus on the downside risks (Ibrahim, 2010). While venture capitalists invest in start-ups that are likely to maximize their returns through a successful exit, venture lenders are focused on gaining constant income streams through regular interest payments during a limited time period. Thus, venture lenders are focused on limiting the downside risk rather than seeking the maximum return. Due to the different business models of these two capital providers, their perception of quality signals based on patents might also be different.

Patents protect inventions and treatments for a long time (e.g., 20 years) and thus secure advantages against competitors by ensuring constant revenues on certain products. Despite these advantages, patents also need a long time horizon until any revenue or profits can be generated. In the meantime, patents can, especially in start-ups, put pressure on liquidity and thus hinder growth and development. For venture lenders, whose business model is based on the start-up's ability to meet interest and principal payments, pending patents could particularly negatively affect the venture's liquidity due to the invention and patenting costs. The term of a 
venture loan might be too short to profit from the revenue-building effect of patents. Granted patents, in particular, put pressure on a firm's future liquidity due to maintaining claims, geographical expansion, or service costs. Additionally, previous costs due to patenting are irrelevant for the venture lender as they are properly captured by the valuation. In addition, even if the patent is used as collateral for the venture lender, it is questionable whether the lender is able to liquidate those intangible assets. These arguments would imply that in contrast to venture capitalists, patents might not be a relevant quality signal for venture lenders. Venture lenders might interpret their claims on the start-up primarily as being dependent on the venture capitalists. Quality signals for the start-up might thus be less relevant.

However, as patents signal quality to venture capitalists, and the involvement of venture capitalists is an essential condition for future equity-financing rounds to pay back venture loans, patents could have a positive effect on the lending decision of venture lenders. Venture lenders are piggybacking off the venture capitalists, and the venture lending business model is centered on extending the liquidity runway of venture capitalists. Despite the fact that venture lenders and venture capitalists are different in their risk perception, overall, we expect that the positive effect of patents on the exclusion of competitors and the prospect of future profits still lead to a quality signal from patents to venture lenders. However, it remains an empirical question whether this expectation can be seen in actual venture lending contracts.

Accordingly, we analyze whether holding patents or patents that are still pending have a positive signaling effect on venture lenders and, as a consequence, reduce capital costs for the borrower. As measures for the capital costs in venture lending contracts, we use the credit spread and the warrant that were applied by the venture lender. The credit spread is the main income source for the venture lender and thus reflects the risk perception of the venture lender regarding the borrower. Furthermore, credit spreads in debt-financing contracts can also be seen as a direct function of the probability of failure (Cressy, 1996). In order to take into account the indirect costs for the borrower, we additionally use the warrant as another variable for measuring capital costs. The warrant has, compared to the credit spread, no direct impact on the borrower's liquidity. Furthermore, it neither has a direct impact on the revenue stream for the venture lender, as the option will only exercise in the case of a liquidation event. Despite the different impacts on the borrower's liquidity, the warrant and credit spread are the main cost drivers for the borrower. For the venture lender, the credit spread ensures constant revenue streams, which have to ensure the intended internal rate of return and the warrant is like a bonus on top of this and constitutes the upside return potential. We hypothesize the following:

H1a: The presence of at least one granted or pending patent reduces the credit spread in venture lending contracts.

H1b: The presence of at least one granted or pending patent reduces the warrant coverage in venture lending contracts.

\section{Firm Maturity and Its Influence on the Relation Between Patents and Capital Costs}

The maturity of a firm influences information asymmetries between start-ups and capital providers (Achleitner, Braun, Lutz, \& Reiner, 2014; Cumming, 2005; Gompers, 1995; Sahlman, 1990). In later stages, more information about the business model is available and future profits and cash flows can be more easily projected (Hellmann \& Puri, 2002). Accordingly, the signaling effect of patents towards venture capitalists is more relevant for early-stage companies that lack other attributes to credibly convey information to venture capitalists (Hsu \& Ziedonis, 2013). There is also evidence from traditional bank loans indicating that a more mature company lifecycle (measured as the loan volume) leads to a decrease in the credit spread (Hanley \& 
Girma, 2006). Consequently, smaller loans are charged a premium price to compensate for their higher risk. Cressy (1996) found that smaller loans are less likely to be collateralized but that the risk adjustment was depicted by higher credit spreads instead. Furthermore, he has shown that larger loans are charged lower credit spreads and that credit spread is a direct function of the probability of failure.

The existing literature focuses on more traditional debt instruments that are used in less innovative contexts than venture lending. For venture lenders, company lifecycle stage is likely to be particularly relevant due to the more pronounced risks than in traditional debt contracts. However, if venture lenders finance companies in an early stage, the negative effect of patents on liquidity might be particularly relevant. This could dampen the impact of maturity on the role of patents.

Companies that are at a later stage, and thus have already exhibited a successful development, might be less dependent on patents to convey information and signal quality whereas younger and premature firms have a higher risk of default due to the liability caused by newness and smallness. Thus, the effect of patents on capital costs is expected to be more relevant for early-stage companies than for later-stage companies. It could be that for venture loans in early-stage companies, an exit lies so far in the future that the impact of patents on the warrant is less pronounced than on the credit spread. We again analyze credit spread and warrant separately and hypothesize the following:

H2a: The effect of patents on the credit spread is stronger for early-stage companies than for later-stage companies in venture lending contracts.

$\mathrm{H} 2 \mathrm{~b}$ : The effect of patents on the warrant coverage is stronger for early-stage companies than for later-stage companies in venture lending contracts.

\section{Empirical Strategy and Descriptive Statistics}

Our study builds on a unique dataset that contains the complete investment history of a European venture lending fund. With detailed deal-level data, we are able to analyze the complex structure of venture lending contracts. In particular, we collected and analyzed the underlying transaction proposals of the fund by which we get the exact information about the contract details of the venture lending deals. Our final sample consists of 119 venture loans that were issued between 2002 and 2009 in Europe, the United States, and Israel. The initial sample contained 132 observations. We deleted four observations because they were classified by the venture lender as working capital or a convertible loan. Another nine observations were deleted due to unavailability of data such as operating profit for the last fiscal year of the companies or the total number of employees in the companies. Table 1 presents the descriptive statistics of our final sample.

\section{Dependent Variables}

Credit spread. As the first dependent variable, we use the credit spread to cover direct and monetary measurable costs for the borrower. We measure credit spread as the difference between the three-year swap rate at the time of the loan issuance and the actual interest rate that was applied in the venture lending deal. We use the three-year swap rate to calculate the credit spread because it is the measure that was used by the venture lender to calculate the risk premium for the venture lending deals. Furthermore, by using the credit spread, we eliminate market fluctuations that arise due to changes in the macroeconomic interest levels. In our data, the credit spread was on average (median) 804.81 (773.60) basis points. For building the variable credit spread, we calculated the weighted average of all tranches that were issued to a company weighted by the amount of each tranche. We use the credit spread to illustrate the costs because it is the main direct-cost driver in venture lending deals. 
Table 1

Sample Description

\begin{tabular}{|c|c|c|c|c|c|c|}
\hline Variables & Description & Mean & Median & Min. & Max. & SD \\
\hline \multicolumn{7}{|l|}{ Independent variables } \\
\hline credit spread & $\begin{array}{l}\text { Credit spread is measured in basis } \\
\text { points between 3-year-swap rate and } 119 \\
\text { actual interest rates }\end{array}$ & 804.81 & 773.60 & 507.10 & $1,269.30$ & 132.08 \\
\hline warrant & $\begin{array}{l}\text { Warrant coverage is expressed in } \\
\text { percent in dependency of the loan } 105 \\
\text { amount }\end{array}$ & 0.1358 & 0.1250 & 0.0450 & 0.2380 & 0.0437 \\
\hline \multicolumn{7}{|l|}{ Firm-specific variables } \\
\hline patents_dummy & $\begin{array}{l}\text { One for the presence of at least one } 119 \\
\text { granted or pending patent }\end{array}$ & 0.54 & 1.00 & 0.00 & 1.00 & 0.50 \\
\hline employees & $\begin{array}{l}\text { Total number of employees in the } 119 \\
\text { borrower's company }\end{array}$ & 68 & 50 & 2 & 331 & 60 \\
\hline valuation & $\begin{array}{l}\text { Valuation of the borrower in } € \text { million } 119 \\
\text { of the last equity round }\end{array}$ & 25.64 & 18.74 & 0.00 & 247.22 & 31.59 \\
\hline drawdowntotal & $\begin{array}{l}\text { Total drawdown of the venture loan in } € 119 \\
\text { million (Includes all tranches) }\end{array}$ & 2.189 & 1.906 & 0.448 & 8.544 & 1.579 \\
\hline op_profit_last_yr & $\begin{array}{l}\text { Operating profit/loss of the last fiscal } 119 \\
\text { year of the borrower in } € \text { million }\end{array}$ & -3.735 & -2.980 & -20.148 & 2.844 & 3.595 \\
\hline country_uk & $\begin{array}{l}\text { One for borrower's headquarter is in the } 119 \\
\text { United Kingdom }\end{array}$ & 0.46 & 0.00 & 0.00 & 1.00 & 0.50 \\
\hline industry_R\&D_intensive & $\begin{array}{l}\text { One for borrower belongs to healthcare } 119 \\
\text { or semiconductor sector }\end{array}$ & 0.29 & 0.00 & 0.00 & 1.00 & 0.46 \\
\hline no_of_vcs & $\begin{array}{l}\text { Number of venture capitalists invested } 119 \\
\text { in the company }\end{array}$ & 3.04 & 3.00 & 1.00 & 8.00 & 1.71 \\
\hline \multicolumn{7}{|l|}{ Environmental variables } \\
\hline vl_deals_total & $\begin{array}{l}\text { Number of venture lending deals in } \\
\text { Europe per year of the three main } 119 \\
\text { suppliers of venture loans in Europe }\end{array}$ & 91.10 & 87.00 & 7.00 & 127.00 & 34.01 \\
\hline vc_volume_europe & $\begin{array}{l}\text { Venture capital volume per year in } 119 \\
\text { Europe in } € \text { million }\end{array}$ & 5,502 & 5,551 & 4,150 & 6,446 & 629 \\
\hline
\end{tabular}

Notes. This table provides descriptive statistics and specification of variables we used in the econometric models. The sample consists of 119 observations and shows that the credit spread is on average 804.81 basis points. The warrant coverage ranges from 0.045 at the lowest to 0.2380 at the highest. The average drawdown is 2.189 million Euro and the companies employ on average 68 people. We also report the number of venture capitalists per company to show that the involvement of venture capitalists is an essential condition to obtain a venture loan. Furthermore, we report environmental variables to control for market changes.

Warrant coverage. As the second dependent variable, we use the warrant coverage to measure indirect costs for the borrower and to represent the lender's option on the borrower's equity stake. Through a warrant, the lender receives the right to exercise an option on a share of the borrower's equity in case of an exit. The option entails the right to purchase a fixed amount of shares at a fixed price. That means, if the valuation of the borrower at the time of an exit is higher compared to the time of the loan issuance, the lender benefits by exercising the equity option. In our sample, the average (median) warrant is $13.58 \%$ (12.50\%), which means that the venture lender is, on average and if, for example, the loan amount is 1 million Euro, able to buy shares to the amount of 135,800 Euro at a fixed price. We use this variable to measure the indirect costs for a borrower in venture lending deals. The number of observations for the variable warrant is reduced due to the fact that the venture lender for some deals applied an exit incentive, which was not expressed in a warrant. 


\section{Independent Variables}

Patents_dummy. The main independent variable of interest indicates whether a start-up has at least one patent granted or at least one patent pending. Due to the fact that pending, as well as granted, patents have a signaling effect, we use a dummy variable that accounts for having at least one patent granted or pending. The variable patents_dummy is coded 1 if the company holds at least one patent or has filed at least one patent, and 0 if otherwise. We use a dummy variable for the analysis because the innovativeness and the signal that is sent by holding a patent depend less on the number of patents a company holds than on holding at least one patent (Mann \& Sager, 2007). In Table 2, we show the patent distribution within our sample. Fifty-four percent of the companies in our sample hold or had filed at least one patent. On average, the companies hold 4.00 patents and have filed 3.84 patents that are still pending, while 39\% already hold granted patents and 35\% of the companies have filed patents that are still pending.

Table 2

Patent Distribution

\begin{tabular}{lllllrr}
\hline Variables & $N$ & Mean & Median & Min. & Max. & SD \\
\hline patents_dummy & 119 & 0.54 & 1 & 0 & 1 & 0.50 \\
patentsgranted & 117 & 4.00 & 0 & 0 & 100 & 11.51 \\
patentsgranted_dummy & 119 & 0.39 & 0 & 0 & 1 & 0.49 \\
patentspending & 117 & 3.84 & 0 & 0 & 51 & 8.15 \\
patentspending_dummy & 119 & 0.35 & 0 & 1 & 0.48 \\
\hline
\end{tabular}

Note. Table 2 presents the patent distribution within our sample's companies and illustrates a heterogeneous distribution.

Independent variables for interaction. For the firm's maturity, we include various proxies and use these variables to interact with the variable patents_dummy to examine the influence of a firm's maturity on the relation between patents and capital costs. First, we use the total number of employees to take account of the firm's lifecycle. In particular, in highly innovative firms that are simultaneously high-growth-potential firms, the number of total employees displays the growth and maturity of an entrepreneurial firm (Davila, Foster, \& Gupta, 2003).

Second, we include the valuation of the company as a proxy for the firm's development stage because the valuation is dependent on factors such as the number of funding rounds, total funding, future development opportunities, and validity of the business model. The valuations were taken from the transaction proposals that were prepared by the venture lender. The variable reflects the valuation of the last equity funding round.

Third, we include the total amount of the venture loans that were issued to depict the maturity of a firm. The higher the total amount of debt the companies obtain, the higher the maturity of those firms (Hanley \& Girma, 2006).

Fourth, we include the operating profit of the last fiscal year as another proxy for maturity. The operating profit or loss indicates whether a start-up is able to create a monetary value that is competitive with other companies. In addition, an operating profit reduces the risk and uncertainty for the debt provider and ensures the repayment of a venture loan. Thus, increasing operating profit indicates a more mature lifecycle of an entrepreneurial firm (Engel \& Keilbach, 2007; Gompers, Kovner, Lerner, \& Scharfstein, 2010).

By taking into account the total number of employees, valuation, total drawdown, and profitability, we increase the robustness of our analysis of how the maturity of a firm has an effect on the relation between patents and capital costs of a venture loan. 
Control variables. In our study, we control for macroeconomic aspects such as the number of venture lending deals and venture capital volume in Europe, as well as the company characteristics like geography and industry. By including the variable vl_deals_total for the total number of venture lending deals, we depict the market sentiment and dynamic of the venture lending market in Europe. A higher activity in the venture lending market might influence capital costs for borrowers due to higher competition among venture lenders, as well as the volatility of demand and supply of venture loans. Thus, the variable vc_volume_europe for the venture capital investment volume in Europe controls for the overall dynamic in the venture capital financing market.

We roughly control for the spatial proximity between the venture lender and the start-ups that have received venture loans by taking into account whether the headquarters of the borrower are in the same country as the venture lender's headquarters. Several studies have shown that the probability of getting funded by venture capitalists decreases if the journey time from the investor to start-up increases (Gupta \& Sapienza, 1992; Lutz, Bender, Achleitner, \& Kaserer, 2013). Additionally, a study that included 14,871 observations from small and medium-sized firms showed that credit spreads increase with the distance between the lender and borrower (Bellucci, Borisov, \& Zazzaro, 2013). Therefore, we include the dummy variable country_uk, which is coded 1 for start-ups with headquarters in the United Kingdom and 0 if otherwise.

Moreover, we control for the industry of the companies that received a venture loan. We subdivided the sample into two groups and build the variable industry_R\&D_intensive, which is coded 1 if the company belongs to an industry that has high research and development costs, such as biotech, pharma, or semiconductors, and 0 if the company is associated with software, e-commerce, or others. By distinguishing these two groups of industries, we differentiate industries in which companies have high R\&D costs and, as a consequence, are faced with higher liquidity pressure due to these costs compared to companies from other industries. As venture lending seeks to extend the cash runway, pressure on liquidity is relevant and has to be considered by including this variable. Additionally, we include year dummies to control for time effects in our regression models.

\section{Methodology}

We conduct ordinary least square (OLS) and Tobit regressions to examine the effect of the presence of granted and pending patents on venture lending capital costs. The regression models are used with clustered errors by company identification numbers and take into account the error term that multiple observations of the start-ups are not independent of each other. Hence, we are able to calculate models with robust errors. Furthermore, we test interaction terms regarding the maturity of the companies to verify our results and to examine whether the maturity of a firm influences the relation between patents and capital costs.

To verify our results and to test the robustness, we conduct a propensity score-matching model. The propensity score-matching model estimates the difference between a treated and non-treated group. In our study, we differentiate between start-ups who have granted or pending patents and those that do not have patents. To match the most suitable pairs of start-ups with and without patents, we run a probit regression to estimate the likelihood of having patents that are dependent upon the matching variables. After that, we match the start-ups with their nearest neighbor, which is measured by the propensity score and the country dummy, to ensure a more precise matching result, and we then run a $t$-test to calculate the mean differences. We remove observations if they are not suitable, i.e., we restrict the maximum distance between a matching pair to a value of 0.1 as measured in the propensity score. 


\section{Empirical Results}

Table 3 reports the results from the OLS and Tobit regression models for the effect of the presence of at least one granted or filed patent on capital costs in venture lending deals which refer to H1a and H1b. In particular, Models 1 and 2 analyze the effect of the variable patents_dummy on the applied credit spread in the venture lending deal, and Models 3 and 4 estimate the effect on the applied warrant in the deal.

Table 3

Results of OLS and Tobit Regression Models

\begin{tabular}{|c|c|c|c|c|}
\hline \multirow{3}{*}{ Variables } & Model 1 & Model 2 & Model 3 & Model 4 \\
\hline & OLS & Tobit & OLS & Tobit \\
\hline & \multicolumn{2}{|c|}{ credit spread } & \multicolumn{2}{|c|}{ warrant } \\
\hline patents_dummy & $\begin{array}{l}-62.58^{* * *} \\
(16.19)\end{array}$ & $\begin{array}{l}-62.58^{* * *} \\
(15.20)\end{array}$ & $\begin{array}{l}-0.0242^{* * *} \\
(0.00657)\end{array}$ & $\begin{array}{l}-0.0242^{* * *} \\
(0.00611)\end{array}$ \\
\hline valuation & $\begin{array}{c}0.0888 \\
(0.533)\end{array}$ & $\begin{array}{c}0.0888 \\
(0.500)\end{array}$ & $\begin{array}{c}0.000107 \\
(0.000210)\end{array}$ & $\begin{array}{c}0.000107 \\
(0.000195)\end{array}$ \\
\hline employees & $\begin{array}{l}-0.0725 \\
(0.227)\end{array}$ & $\begin{array}{l}-0.0725 \\
(0.213)\end{array}$ & $\begin{array}{l}-0.0000826 \\
-0.0000754\end{array}$ & $\begin{array}{l}-0.0000826 \\
-0.0000702\end{array}$ \\
\hline drawdowntotal & $\begin{array}{r}-18.12^{* *} \\
(8.490)\end{array}$ & $\begin{array}{c}-18.12^{* *} \\
(7.970)\end{array}$ & $\begin{array}{l}-0.0111^{* * *} \\
(0.00285)\end{array}$ & $\begin{array}{l}-0.0111^{* * *} \\
(0.00265)\end{array}$ \\
\hline op_profit_last_yr & $\begin{array}{l}-7.181^{* *} \\
(3.002)\end{array}$ & $\begin{array}{l}-7.181^{* *} \\
(2.818)\end{array}$ & $\begin{array}{l}-0.00227^{*} \\
(0.00128)\end{array}$ & $\begin{array}{l}-0.00227^{*} \\
(0.00119)\end{array}$ \\
\hline vl_deals_total & $\begin{array}{l}-0.0883 \\
(0.300)\end{array}$ & $\begin{array}{c}0.854 \\
(0.753)\end{array}$ & $\begin{array}{l}-0.000203 \\
(0.000290)\end{array}$ & $\begin{array}{l}-0.000340 \\
(0.000220)\end{array}$ \\
\hline vc_volume_europe & $\begin{array}{l}-0.0746 \\
(0.0518)\end{array}$ & $\begin{array}{l}-0.141^{* * *} \\
(0.0298)\end{array}$ & $\begin{array}{l}-0.0000133 \\
-0.0000269\end{array}$ & $\begin{array}{l}-0.00000361 \\
-0.00000722\end{array}$ \\
\hline country_uk & $\begin{array}{c}17.74 \\
(15.92)\end{array}$ & $\begin{array}{c}17.74 \\
(14.94)\end{array}$ & $\begin{array}{l}-0.00636 \\
(0.00701)\end{array}$ & $\begin{array}{l}-0.00636 \\
(0.00652)\end{array}$ \\
\hline industry_R\&D_intensive & $\begin{array}{c}40.33^{* *} \\
(18.32)\end{array}$ & $\begin{array}{c}40.33^{* *} \\
(17.20)\end{array}$ & $\begin{array}{c}0.0188^{* *} \\
(0.00804)\end{array}$ & $\begin{array}{c}0.0188^{* *} \\
(0.00747)\end{array}$ \\
\hline Year dummies & Yes & Yes & Yes & Yes \\
\hline Constant & $\begin{array}{c}1,382^{* * *} \\
(274.3)\end{array}$ & $\begin{array}{c}1,632^{* * *} \\
(142.1)\end{array}$ & $\begin{array}{c}0.240^{*} \\
(0.125)\end{array}$ & $\begin{array}{c}0.204^{* * *} \\
(0.0401)\end{array}$ \\
\hline Observations & 119 & 119 & 105 & 105 \\
\hline$R$-squared & 0.551 & & 0.622 & \\
\hline
\end{tabular}

Notes. Table 3 presents estimates of the OLS and Tobit regressions to examine the effect of the presence of at least one granted or filed patent on the applied credit spread or warrant in venture lending deals. Models 1 and 3 report the estimates for the OLS regressions and Models 2 and 4 report the estimates for Tobit regressions. The number of observations varies because in some cases, there was no warrant applied. Robust standard errors are in parentheses. The symbols *, ${ }^{* *}$, and ${ }^{* * *}$ denote statistical significance at the $10 \%, 5 \%$, and $1 \%$ level, respectively.

The regression results for Models 1 and 2 show evidence that the presence of granted or pending patents has an effect on the credit spread of the venture loans. The variable patents_dummy shows a significant and negative effect at the $1 \%$ significance level. The regression coefficients in Models 1 and 2 reveal that if a company holds or has filed at least one patent, the credit spread decreases by 62.58 basis points, which shows an economically relevant negative effect of patents on credit spread. Furthermore, Models 3 and 4 also show evidence that patents also have an effect on the warrant. The results are significant at the $1 \%$ level and indicate 
a reduction in the warrant coverage of 2.42 percentage points if the company has pending or granted patents. The high $R$-squared values of 0.551 in Model 1 and 0.622 in Model 3 show that we have considered the key variables in our regression models. Our results confirm H1a and H1b that the presence of granted or pending patents has an effect on capital costs in venture lending contracts both on credit spread and warrant coverage. Thus, patents serve as a signal for the quality of entrepreneurial firms and convey relevant information regarding the downside risk for venture lenders.

In Table 4, we show the interaction effects between the independent variable patents_dummy and the variables total number of employees, valuation, total drawdown, and operating profit, which are used as proxies for the maturity of a firm. We present four regressions models that illustrate the effect of the maturity of a firm on the relation between patents and credit spread.

Table 4

Results for Interaction With Proxies for Maturity on Credit Spread

\begin{tabular}{|c|c|c|c|c|}
\hline \multirow{2}{*}{ Variables } & Model 1 & Model 2 & Model 3 & Model 4 \\
\hline & credit spread & credit spread & credit spread & credit spread \\
\hline patents_dummy & $\begin{array}{c}-117.0^{* * * *} \\
(25.57)\end{array}$ & $\begin{array}{l}-99.52^{* * *} \\
(21.70)\end{array}$ & $\begin{array}{l}-97.09^{* * *} \\
(25.66)\end{array}$ & $\begin{array}{l}-88.59^{* * *} \\
(20.87)\end{array}$ \\
\hline patents_dummy*employees & $\begin{array}{c}0.779^{* *} \\
(0.340)\end{array}$ & & & \\
\hline patents_dummy*valuation & & $\begin{array}{l}1.585^{* *} \\
(0.653)\end{array}$ & & \\
\hline patents_dummy*drawdowntotal & & & $\begin{array}{l}16.00^{*} \\
(9.543)\end{array}$ & \\
\hline patents_dummy*op_profit_last_yr & & & & $\begin{array}{l}-8.021^{*} \\
(4.485)\end{array}$ \\
\hline employees & $\begin{array}{l}-0.601^{*} \\
(0.307)\end{array}$ & $\begin{array}{l}-0.0359 \\
(0.212)\end{array}$ & $\begin{array}{l}-0.105 \\
(0.226)\end{array}$ & $\begin{array}{l}-0.0601 \\
(0.227)\end{array}$ \\
\hline valuation & $\begin{array}{c}0.0648 \\
(0.473)\end{array}$ & $\begin{array}{l}-1.323^{* *} \\
(0.621)\end{array}$ & $\begin{array}{c}0.101 \\
(0.541)\end{array}$ & $\begin{array}{l}-0.0710 \\
(0.504)\end{array}$ \\
\hline drawdowntotal & $\begin{array}{r}-18.22^{* *} \\
(7.671)\end{array}$ & $\begin{array}{l}-12.80 \\
(8.485)\end{array}$ & $\begin{array}{c}-26.71^{* * * *} \\
(7.404)\end{array}$ & $\begin{array}{c}-15.96^{*} \\
(8.266)\end{array}$ \\
\hline op_profit_last_yr & $\begin{array}{l}-7.015^{* *} \\
(2.813)\end{array}$ & $\begin{array}{l}-5.966^{*} \\
(3.098)\end{array}$ & $\begin{array}{l}-6.856^{* *} \\
(3.016)\end{array}$ & $\begin{array}{l}-1.964 \\
(3.836)\end{array}$ \\
\hline vl_deals_total & $\begin{array}{l}-0.361 \\
(0.885)\end{array}$ & $\begin{array}{c}0.275 \\
(0.801)\end{array}$ & $\begin{array}{c}0.776 \\
(0.785)\end{array}$ & $\begin{array}{c}0.527 \\
(0.805)\end{array}$ \\
\hline vc_volume_europe & $\begin{array}{l}-0.143^{* * *} \\
(0.0299)\end{array}$ & $\begin{array}{l}-0.143^{* * *} \\
(0.0321)\end{array}$ & $\begin{array}{l}-0.145^{* * *} \\
(0.0317)\end{array}$ & $\begin{array}{l}-0.140^{* * *} \\
(0.0319)\end{array}$ \\
\hline country_uk & $\begin{array}{c}13.73 \\
(15.59)\end{array}$ & $\begin{array}{l}18.28 \\
(16.11)\end{array}$ & $\begin{array}{l}15.36 \\
(15.91)\end{array}$ & $\begin{array}{c}14.25 \\
(16.48)\end{array}$ \\
\hline industry_R\&D_intensive & $\begin{array}{l}47.37^{* * *} \\
(17.48)\end{array}$ & $\begin{array}{c}45.16^{* *} \\
(18.39)\end{array}$ & $\begin{array}{c}40.90^{* *} \\
(18.32)\end{array}$ & $\begin{array}{c}36.94^{* *} \\
(17.93)\end{array}$ \\
\hline Year dummies & Yes & Yes & Yes & Yes \\
\hline Constant & $\begin{array}{r}1,830^{* * * *} \\
(158.5)\end{array}$ & $\begin{array}{r}1,729^{* * *} \\
(160.1)\end{array}$ & $\begin{array}{r}1,680^{* * * *} \\
(155.7)\end{array}$ & $\begin{array}{r}1,679^{* * * *} \\
(158.1)\end{array}$ \\
\hline Observations & 119 & 119 & 119 & 119 \\
\hline$R$-squared & 0.573 & 0.568 & 0.558 & 0.558 \\
\hline
\end{tabular}

Notes. Table 4 presents the results of the interaction effects of maturity of a firm on the relation between the presence of at least one or granted patent on credit spread. To estimate the effect, we use OLS regression. Robust standard errors are in parentheses. The symbols ${ }^{*}, * *$, and ${ }^{* * *}$ denote statistical significance at the $10 \%, 5 \%$, and $1 \%$ level, respectively. 
In Models 1-4, we interact the variable patents_dummy and the proxies for maturity to analyze the moderation effect of the proxies on the relation between the presence of at least one granted or pending patent and credit spread. Models 1 and 2 show the interaction term between patents and employees, as well as the valuation of the company, which are significant at the $5 \%$ level and indicate that the total number of employees and the valuation of the company negatively influence the relation between patents and credit spread. Furthermore, Model 3 indicates that the total drawdown also has a negative impact on the relation between patents and credit spread, which is significant at the $10 \%$ level. This result is in line with the previous interaction term result that the impact of patents is also influenced by the maturity of the firm. In Model 4, we estimate the effect of the operating profit on the relation between patents and credit spread, but we could not find evidence for an interaction as the variable operating profit is not significant.

To illustrate and interpret our results, we plot the significant interaction terms (see Figures 1, 2, and 3 below) of employees, valuation, and drawdown on the relation between patents and credit spread. Figure 1 illustrates that if the total number of employees is low (high), represented as the mean minus (plus) one standard deviation, the presence of patents is more (less) relevant. Furthermore, the gradient of the slope for a small number of employees is considerably higher (-105.01) compared to the gradient of the slope for a large number of employees (-15.93). This means that the effect of the interaction term on the relation between patents and credit spread is also of economic importance for the borrower, which is reflected in considerably higher credit spread if the company is at an earlier stage and does not have any patents. This shows that the presence of patents has a higher impact on credit spread for less mature firms and that the more mature a firm is, the less important is the presence of patents.

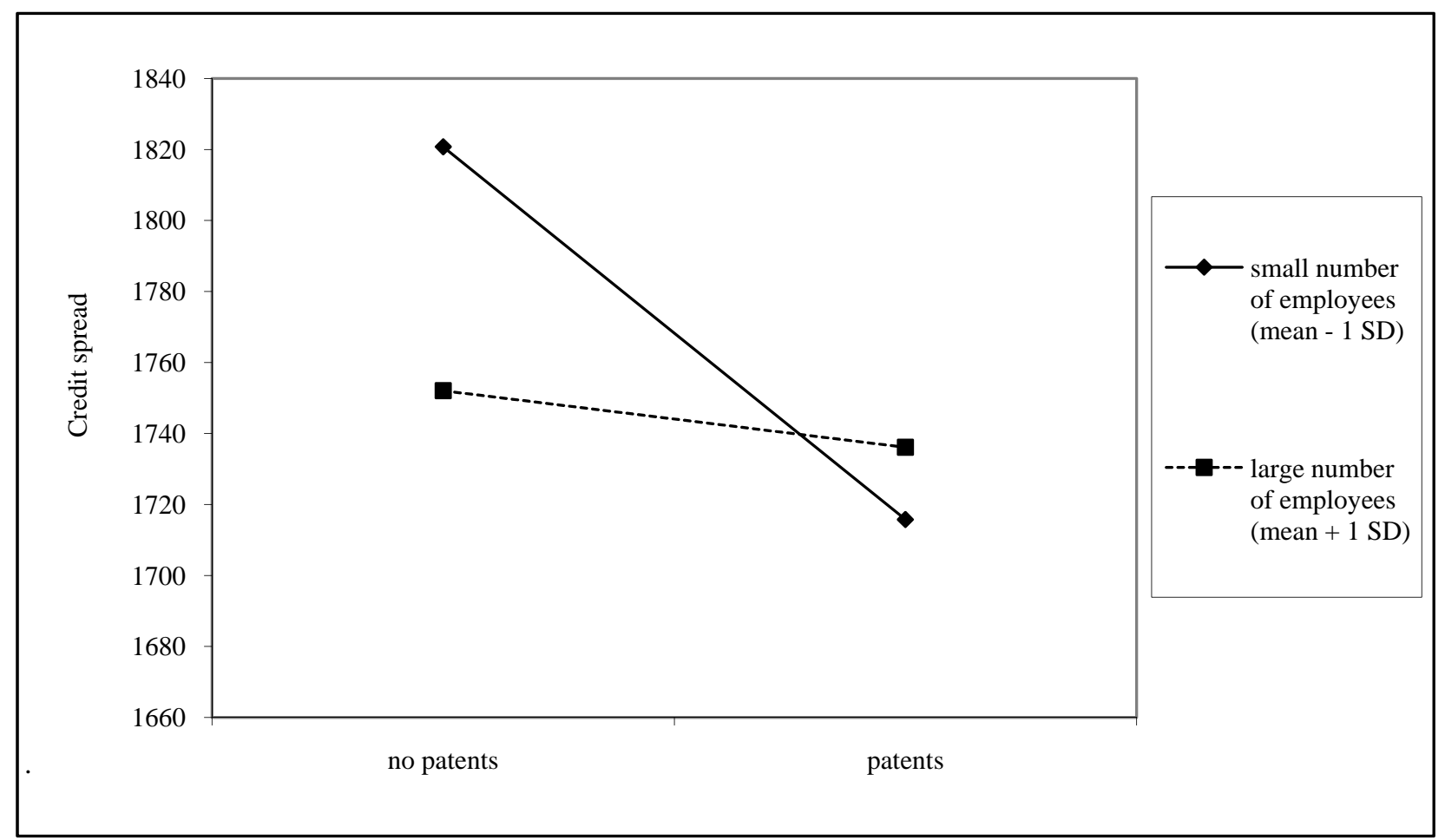

Figure 1. Plot of the interaction effect of employees on the relation between the presence of at least one granted or pending patent and the credit spread in venture lending contracts. 
In Figure 2, we present the plot of the interaction of valuation on the relation between patents and credit spread. This plot also illustrates that a high (low) valuation, represented as the mean plus (minus) one standard deviation, reinforces (mitigates) the effect of patents on the credit spread. The economic effect is similarly strong to the effect of the total number of employees on this relation. The gradient of the slope for a low valuation is -102.92 compared to a gradient of -7.56 for a high valuation.

Another interaction term, the variable total drawdown, shows similar effects at a significance level of $10 \%$, which is not as strong as the effect of the previous proxies for maturity. Figure 3 clarifies that the effect of the total drawdown as an interaction term with patents is weaker due to a smaller difference between the gradients of the slopes for low (-86.70) and high drawdown (-25.15) but is still economically relevant. This result is plotted in Figure 3.

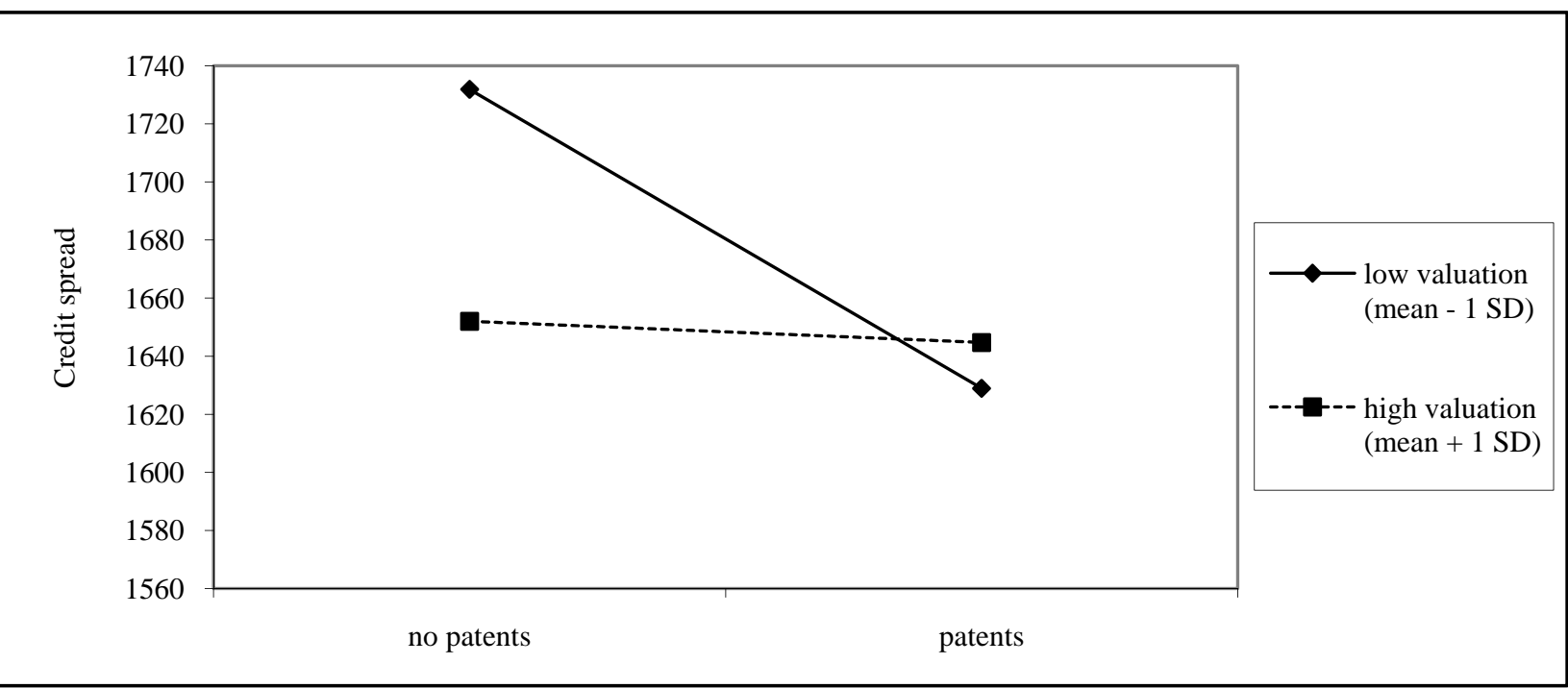

Figure 2. Plot of the interaction effect of the valuation on the relation between the presence of at least one granted or pending patent and the credit spread in venture lending contracts.

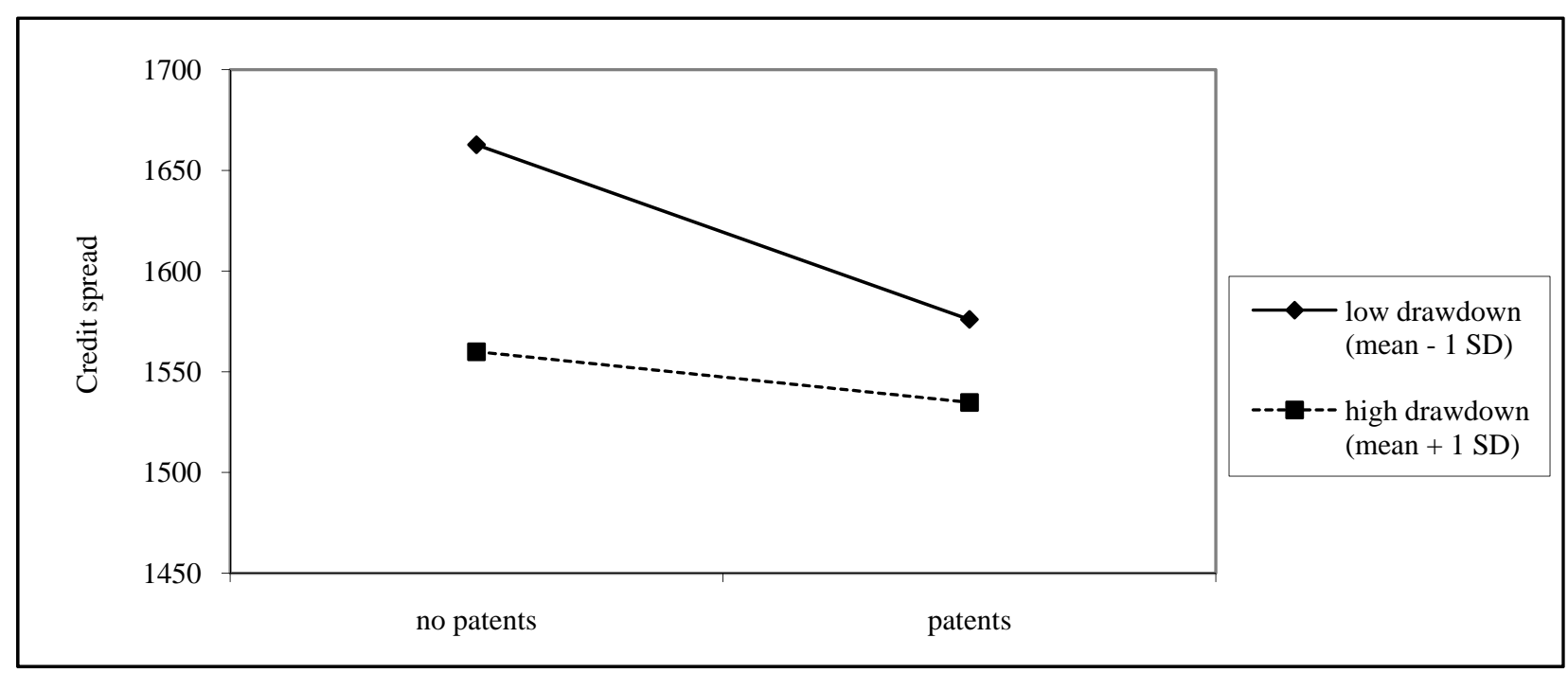

Figure 3. Plot of the interaction effect of the total drawdown on the relation between the presence of at least one granted or pending patent and the credit spread in venture lending contracts. 
Overall, we show that three out of four proxies of a firm's maturity significantly moderate the effect of patents on credit spread. Our results suggest that patents have a more relevant effect on early-stage companies than on later-stage companies. Thus, patent signaling seems to be stronger regarding venture lenders when companies are in early development stages.

In Table 5, we present the results for the interaction with the variable warrant coverage as the dependent variable. The interactions between the presence of patents and employees, valuation, and total drawdown, as well as operating profit, do not reveal any statistically significant effects on the indirect costs of a venture loan. Nevertheless, the results point in the expected direction. This could be a hint that the maturity of a firm also influences the warrant in venture lending contracts even though it is not statistically significant.

Table 5

Results for Interaction With Proxies for Maturity on Warrant

\begin{tabular}{|c|c|c|c|c|}
\hline \multirow{2}{*}{ Variables } & Model 1 & Model 2 & Model 3 & Model 4 \\
\hline & warrant & warrant & warrant & warrant \\
\hline patents_dummy & $\begin{array}{l}-0.0281^{* *} \\
(0.0109)\end{array}$ & $\begin{array}{l}-0.0344^{* * * *} \\
(0.00953)\end{array}$ & $\begin{array}{l}-0.0263^{* *} \\
(0.0120)\end{array}$ & $\begin{array}{l}-0.0192^{*} \\
(0.0101)\end{array}$ \\
\hline patents_dummy*employees & $\begin{array}{r}0.0000619 \\
(0.000131) \\
\end{array}$ & & & \\
\hline patents_dummy*valuation & & $\begin{array}{c}0.000459^{*} \\
(0.000231) \\
\end{array}$ & & \\
\hline patents_dummy*drawdowntotal & & & $\begin{array}{r}0.000974 \\
(0.00382) \\
\end{array}$ & \\
\hline patents_dummy*op_profit_last_yr & & & & $\begin{array}{c}0.00161 \\
(0.00214) \\
\end{array}$ \\
\hline employees & $\begin{array}{l}-0.000114 \\
-0.0000766\end{array}$ & $\begin{array}{l}-0.0000479 \\
-0.0000836\end{array}$ & $\begin{array}{l}-0.0000813 \\
-0.0000753\end{array}$ & $\begin{array}{l}-0.0000806 \\
-0.0000772\end{array}$ \\
\hline valuation & $\begin{array}{r}0.0000932 \\
(0.000209) \\
\end{array}$ & $\begin{array}{l}-0.000328 \\
(0.000281)\end{array}$ & $\begin{array}{c}0.000105 \\
(0.000212) \\
\end{array}$ & $\begin{array}{c}0.000135 \\
(0.000216)\end{array}$ \\
\hline drawdowntotal & $\begin{array}{l}-0.0109^{* * *} \\
(0.00277)\end{array}$ & $\begin{array}{l}-0.00897^{* * *} \\
(0.00301)\end{array}$ & $\begin{array}{l}-0.0116^{* * *} \\
(0.00295)\end{array}$ & $\begin{array}{l}-0.0115^{* * *} \\
(0.00299)\end{array}$ \\
\hline op_profit_last_yr & $\begin{array}{l}-0.00219^{*} \\
(0.00125)\end{array}$ & $\begin{array}{l}-0.00181 \\
(0.00127)\end{array}$ & $\begin{array}{l}-0.00224^{*} \\
(0.00128)\end{array}$ & $\begin{array}{l}-0.00337^{* *} \\
(0.00156)\end{array}$ \\
\hline vl_deals_total & $\begin{array}{l}-0.000414^{*} \\
(0.000230)\end{array}$ & $\begin{array}{l}-0.000467^{* *} \\
(0.000223)\end{array}$ & $\begin{array}{l}-0.000340 \\
(0.000236)\end{array}$ & $\begin{array}{l}-0.000265 \\
(0.000251)\end{array}$ \\
\hline vc_volume_europe & $\begin{array}{l}-0.00000396 \\
-0.00000783\end{array}$ & $\begin{array}{l}-0.00000397 \\
-0.00000779\end{array}$ & $\begin{array}{l}-0.00000377 \\
-0.00000777\end{array}$ & $\begin{array}{l}-0.00000383 \\
-0.00000777 \\
\end{array}$ \\
\hline country_uk & $\begin{array}{l}-0.00638 \\
(0.00706) \\
\end{array}$ & $\begin{array}{l}-0.00539 \\
(0.00700) \\
\end{array}$ & $\begin{array}{l}-0.00640 \\
(0.00703) \\
\end{array}$ & $\begin{array}{l}-0.00581 \\
(0.00715)\end{array}$ \\
\hline industry_R\&D_intensive & $\begin{array}{c}0.0195^{* *} \\
(0.00855) \\
\end{array}$ & $\begin{array}{c}0.0200^{* *} \\
(0.00839)\end{array}$ & $\begin{array}{c}0.0189^{* *} \\
(0.00814) \\
\end{array}$ & $\begin{array}{c}0.194^{* *} \\
(0.00799)\end{array}$ \\
\hline Year dummies & Yes & Yes & Yes & Yes \\
\hline Constant & $\begin{array}{c}0.217^{* * *} \\
(0.0428)\end{array}$ & $\begin{array}{c}0.224^{* * *} \\
(0.0436)\end{array}$ & $\begin{array}{c}0.205^{* * *} \\
(0.0432)\end{array}$ & $\begin{array}{c}0.192^{* * *} \\
(0.044)\end{array}$ \\
\hline Observations & 105 & 105 & 105 & 105 \\
\hline$R$-squared & 0.623 & 0.635 & 0.622 & 0.625 \\
\hline
\end{tabular}

Notes. Table 5 presents the results of the interaction effects of maturity of a firm on the relation between the presence of at least one or granted patent on warrant. To estimate the effect, we use OLS regressions. Robust standard errors are in parentheses. The symbols ${ }^{* * *}$, and ${ }^{* * *}$ denote statistical significance at the $10 \%, 5 \%$, and $1 \%$ level, respectively.

Regarding the included control variables, the macroeconomic variables, as well as the geographic variable, do not have any effect on the capital costs. The regression estimates a significantly positive effect of the variable for high R\&D expenditures on loan costs, which is in line with higher information asymmetries in those industries. 


\section{Robustness Check}

By applying the matching procedure, we control for endogeneity problems, which may arise from unobservable factors that potentially affect both the dependent and independent variables. Unobservable factors in our econometric model, such as the qualification and job experience of employees, could influence the capital costs in venture lending deals. So far, we have not controlled for a selection bias, which arises due to the constellation the quality signal does not stem from the patents the company owns but from the employees behind the inventions. Therefore, we apply the matching model to verify our results. The results of the matching model are shown in Table 6.

Table 6

Results for Matching

\begin{tabular}{lrrl}
\hline Variables & $N$ & Mean delta & $\begin{array}{l}\text { Result of } t \text {-test on mean } \\
\text { difference }\end{array}$ \\
\hline Outcome variables & & & \\
\hline credit spread & 52 & 57.5896 & Significant at 5\% level \\
warrant & 41 & 0.0214 & Significant at 5\% level \\
\hline Marketing variables & & \\
\hline employees & & 13.4808 & Not significant \\
drawdowntotal & 0.2064 & Not significant \\
op_profit_last_yr & -0.3309 & Not significant \\
vl_deals_total & -6.7692 & Not significant \\
vc_volume_europe & & -115.4212 & Not significant \\
industry_R\&D_intensive & -0.0577 & Not significant \\
Year dummies & Not reported & Not significant
\end{tabular}

Notes. This table displays the results of the propensity score-matching model. $N=$ Number of matched pairs.

The results of the propensity score-matching confirm our results that the presence of granted or pending patents influences the direct and indirect costs of a venture loan. The results also show that we can control for the endogeneity problem and that our results are robust. Regarding credit spread, we have matched 52 pairs, whereas, in the analysis of warrants, we matched 41 pairs. The mean delta of the credit spread shows a difference of 57.59 basis points between start-ups with and without patents, which is significant at the $5 \%$ level. The mean delta of the warrants shows a difference of 0.0214 between the two groups, which is also significant at the $5 \%$ level. The $t$-tests referring to the matching variables are not significant and confirm the robustness of the results.

\section{Conclusion}

In this study, our aim was to investigate whether patents convey information about the downside risk of a young and innovative company and thus are able to serve as a quality signal for venture lenders. We set out to empirically examine the influence of patents on direct as well as indirect capital costs of the borrower. Moreover, we were interested in identifying contexts in which the business and financial risks of the start-up are high, thus leading to a particularly strong impact of patents as a quality signal. Our study is based on a unique dataset consisting of 119 deals of a European venture lending fund issued between 2002 and 2009 in Europe, the United States, and Israel. 
We find that the presence of at least one granted or pending patent negatively influences the credit spread and the warrant in venture lending contracts, which indicates that the signaling effect of patents is prevalent in venture lending deals. Despite a negative impact on liquidity during the term of the loan, patents serve as a valuable signal for venture lenders and reduce both direct and indirect costs of the borrower. We further investigated whether the maturity of the start-up has an impact on the importance of patents as a quality signal for the venture lender. For this purpose, we used different proxies for the maturity of start-ups including the number of employees, the valuation of the last equity-financing round, the total loan drawdown, and the operating profit. The effect of patents on the credit spread is stronger for early-stage companies than for later-stage companies. Start-ups can hence profit from patents, particularly in early development stages. In contrast, we do not find significant evidence that the company stage influences the relation between patents and warrant coverage. The warrant represents an additional income possibility for the venture lender that only becomes relevant in the case of a successful exit. It might be that even in later-stage deals, the possibility of a successful exit is still so uncertain that the role of patents remains equally important as in early-stage deals. However, in light of our small sample size, this non-significant result has to be interpreted with caution.

With our study, we make various contributions to the literature. First, we extend the entrepreneurial finance literature by providing empirical insights into an innovative debt-based financing instrument in the context of entrepreneurial firms, which are characterized by the unavailability of tangible securities and high business risks as well as financial risks. The existing venture lending literature has theoretically or experimentally examined factors that influence the lending decision and what the underlying lending criteria are (Fischer \& De Rassenfosse, 2012; Ibrahim, 2010). With our study, we contribute to this literature by empirically examining how patents influence the terms of lending contracts and thus the future liquidity of the innovative young companies receiving the venture loans. In addition, we add to the patent signaling theory by showing that despite the negative effect of patents on the liquidity of start-ups, patents serve as a quality signal for venture lenders. The positive effect of patents on the exclusion of competitors and the prospect of future profits seems to outweigh the negative impact on short-term liquidity.

Various limitations need to be taken into account when considering our results, but these may also become starting points for new studies on venture lending. The results we have shown have to be considered under the limitation that our sample stems from a single European venture lending fund. Hence, our results are not necessarily representative for other venture lenders; however, the behavior of venture lenders is likely to be similar due to this specialized financing instrument being targeted towards a niche group of appropriate target firms. Additionally, as we use one venture lending fund, we are able to provide a tight control group regarding the decision-making process of our sample.

As the prior literature suggests, an important factor for venture lenders is the prior involvement of venture capitalists in the start-up. Our study does not take into account potential differences between venture capitalists and their influence on the terms of venture loans. Additionally, it would be interesting to investigate whether networks between the venture lender and venture capitalists lead to differences in venture lending contracts. The involvement of corporate venture capitalists may have a stronger impact on loan-cost drivers than other investors due to their strategic advantages and access to technological support from the corporate sector (Dushnitsky \& Lenox, 2006). Furthermore, several studies have confirmed that the founders and the 
management team are important for a firm's success and development. In the context of venture lending, it would be relevant to analyze the role of the founding team in structuring venture lending contracts. We encourage future quantitative empirical studies in these directions to better understand venture lending as an innovative form of financing for entrepreneurial companies.

\section{References}

Achleitner, A. K., Braun, R., \& Kohn, K. (2011). New venture financing in Germany: Effects of firm and owner characteristics. Zeitschrift für Betriebswirtschaft, 81(3), 263-294. doi: 10.1007/s11573-011-0441-3

Achleitner, A. K., Braun, R., Lutz, E., \& Reiner, U. (2014). Industry relatedness in trade sales and venture capital investment returns. Small Business Economics, 43(3), 621-637.

Audretsch, D. B., Bönte, W., \& Mahagaonkar, P. (2012). Financial signaling by innovative nascent ventures: The relevance of patents and prototypes. Research Policy, 41(8), 1407-1421.

Bellucci, A., Borisov, A., \& Zazzaro, A. (2013). Do banks price discriminate spatially? Evidence from small business lending in local credit markets. Journal of Banking \& Finance, 37(11), 4183-4197.

Berger, A. N., \& Udell, G. F. (1990). Collateral, loan quality and bank risk. Journal of Monetary Economics, 25(1), 21-42.

Berger, A. N., \& Udell, G. F. (1998). The economics of small business finance: The roles of private equity and debt markets in the financial growth cycle. Journal of Banking \& Finance, 22(6-8), 613-673.

Block, J. H., De Vries, G., Schumann, J. H., \& Sandner, P. (2014). Trademarks and venture capital valuation. Journal of Business Venturing, 29(4), 525-542.

Bloom, N., \& Van Reenen, J. (2002). Patents, real options and firm performance. The Economic Journal, 112(478), C97-C116.

Brüderl, J., Preisendörfer, P., \& Ziegler, R. (1992). Survival chances of newly founded business organizations. American Sociological Review, 57(2), 227-242.

Cao, J., \& Hsu, P. H. (2011). The informational role of patents in venture capital financing. Working Paper, Singapore Management University, University of Connecticut.

Cockburn, I. M., \& MacGarvie, M. J. (2011). Entry and patenting in the software industry. Management Science, 57(5), 915-933. doi: $10.1287 /$ mnsc.1110.1321

Colombo, M. G., \& Grilli, L. (2007). Funding gaps? Access to bank loans by high-tech start-ups. Small Business Economics, 29(1), 25-46.

Conti, A., Thursby, M. C., \& Rothaermel, F. T. (2013). Show me the right stuff: Signals for high-tech startups. Journal of Economics \& Management Strategy, 22(2), 341-364.

Cosh, A., Cumming, D., \& Hughes, A. (2009). Outside enterpreneurial capital. The Economic Journal, 119(540), 1494-1533.

Cressy, R. (1996). Commitment lending under asymmetric information: Theory and tests on U.K. startup data. Small Business Economics, 8(5), 397-408.

Cumming, D. J. (2005). Agency costs, institutions, learning, and taxation in venture capital contracting. Journal of Business Venturing, 20(5), 573-622. doi: 10.1016/j.jbusvent.2003.07.001

Cumming, D. J. (2007). United States venture capital financial contracting: Foreign securities. In M. Hirschey, K. John, \& A. K. Makhija (Eds.), Issues in corporate governance and finance (Advances in Financial Economics, Vol. 12, pp. 405-444). Emerald Group Publishing Limited.

Cumming, D. J., \& Fleming, G. A. (2013). Debt investments in private firms: Legal institutions and investment performance in 25 countries. Journal of Fixed Income, 23(1), 102-123.

Davila, A., Foster, G., \& Gupta, M. (2003). Venture capital financing and the growth of startup firms. Journal of Business Venturing, 18(6), 689-708.

De Bettignies, J. E., \& Brander, J. A. (2007). Financing entrepreneurship: Bank finance versus venture capital. Journal of Business Venturing, 22(6), 808-832. doi: 10.1016/j.jbusvent.2006.07.005

Denis, D. J. (2004). Entrepreneurial finance: An overview of the issues and evidence. Journal of Corporate Finance, 10(2), 301-326.

Dushnitsky, G., \& Lenox, M. J. (2006). When does corporate venture capital investment create firm value? Journal of Business Venturing, 21(6), 753-772.

Engel, D., \& Keilbach, M. (2007). Firm-level implications of early stage venture capital investment-An empirical investigation. Journal of Empirical Finance, 14(2), 150-167. 
Fischer, T., \& De Rassenfosse, G. (2012). Venture debt financing: Determinants of the lending decision. Working Paper, Technische Universität München, The University of Melbourne.

Gompers, P. A. (1995). Optimal investment, monitoring, and the staging of venture capital. The Journal of Finance, 50(5), 1461-1489.

Gompers, P., Kovner, A., Lerner, J., \& Scharfstein, D. (2010). Performance persistence in entrepreneurship. Journal of Financial Economics, 96(1), 18-32.

Gupta, A. K., \& Sapienza, H. J. (1992). Determinants of venture capital firms' preferences regarding the industry diversity and geographic scope of their investments. Journal of Business Venturing, 7(5), 347-362.

Haeussler, C., Harhoff, D., \& Mueller, E. (2014). How patenting informs VC investors - The case of biotechnology. Research Policy, 43(8), 1286-1298.

Hall, B. H., \& Harhoff, D. (2012). Recent research on the economics of patents. Annual Review of Economics, 4, 541-565.

Hanley, A., \& Girma, S. (2006). New ventures and their credit terms. Small Business Economics, 26(4), 351-364. doi: 10.1007/s11187-005-3200-4

Hellmann, T., \& Puri, M. (2002). Venture capital and the professionalization of start-up firms: Empirical evidence. The Journal of Finance, 57(1), 169-197.

Hochberg, Y. V., Serrano, C. J., \& Ziedonis, R. H. (2014). Patent collateral, investor commitment, and the market for venture lending. Working Paper, Rice University, Universitat Pompeu Fabra, University of Oregon.

Hsu, D. H., \& Ziedonis, R. H. (2013). Resources as dual sources of advantage: Implications for valuing entrepreneurial-firm patents. Strategic Management Journal, 34(7), 761-781.

Ibrahim, D. M. (2010). Debt as venture capital. University of Illinois Law Review, Vol. 2010, pp. 1169-1210, Legal Studies Research Paper Series, Paper No. 1081.

Kamiyama, S., Sheehan, J., \& Martinez, C. (2006). Valuation and exploitation of intellectual property. OECD Science, Technology and Industry Working Papers, 2006/05.

Kaplan, S. N., \& Strömberg, P. (2004). Characteristics, contracts, and actions: Evidence from venture capitalist analyses. The Journal of Finance, 59(5), 2177-2210.

Lerner, J. (1994). The importance of patent scope: An empirical analysis. The RAND Journal of Economics, 25(2), 319-333.

Long, C. (2002). Patent signals. The University of Chicago Law Review, 69(2), 625-679.

Lutz, E., Bender, M., Achleitner, A. K., \& Kaserer, C. (2013). Importance of spatial proximity between venture capital investors and investees in Germany. Journal of Business Research, 66(11), 2346-2354.

Mann, R. J. (2005). Do patents facilitate financing in software industry? Texas Law Review, 83(4), 961-1030.

Mann, R. J., \& Sager, T. W. (2007). Patents, venture capital, and software start-ups. Research Policy, 36(2), 193-208.

Rhodes-Kropf, M., \& Leamon, A. (2010). Avid radiopharmaceuticals and lighthouse capital partners. Harvard Business School Case (9-810-054), 1-15.

Roberts, M. J., Sahlman, W. A., \& Kind, L. (2008). Pinnacle Ventures Harvard Business School Case (Vol. 9-808-0148). Harvard Business School Publishing.

Sahlman, W. A. (1990). The structure and governance of venture-capital organizations. Journal of Financial Economies, 27(2), 473-521.

Sandner, P. G., \& Block, J. (2011). The market value of R\&D, patents, and trademarks. Research Policy, 40(7), 969-985.

Teece, D. J. (1986). Profiting from technological innovation: Implications for integration, collaboration, licensing and public policy. Research Policy, 15(6), 285-305.

Westhead, P., \& Storey, D. J. (1997). Financial constraints on the growth of high technology small firms in the United Kingdom. Applied Financial Economics, 7(2), 197-201. 